\title{
What Motivates Students to Study Engineering? A Comparative Study between Males and Females in Saudi Arabia
}

\author{
Wafa Labib $^{1, *}$, Amal Abdelsattar ${ }^{1}$, Yasser Ibrahim ${ }^{2}$ and Abdelhakim Abdelhadi ${ }^{2}$ \\ 1 Architecture Department, Prince Sultan University, P.O. Box 66833, Riyadh 12435, Saudi Arabia; \\ aabdelsattar@psu.edu.sa \\ 2 Engineering Management Department, Prince Sultan University, P.O. Box 66833, Riyadh 12435, Saudi Arabia; \\ ymansour@psu.edu.sa (Y.I.); abdelhadi@psu.edu.sa (A.A.) \\ * Correspondence: wlabib@psu.edu.sa
}

Citation: Labib, W.; Abdelsattar, A.; Ibrahim, Y.; Abdelhadi, A. What Motivates Students to Study Engineering? A Comparative Study between Males and Females in Saudi Arabia. Educ. Sci. 2021, 11, 147. https://doi.org/10.3390/

educsci11040147

Academic Editor: James Albright

Received: 25 February 2021

Accepted: 19 March 2021

Published: 25 March 2021

Publisher's Note: MDPI stays neutral with regard to jurisdictional claims in published maps and institutional affiliations.

Copyright: (c) 2021 by the authors. Licensee MDPI, Basel, Switzerland. This article is an open access article distributed under the terms and conditions of the Creative Commons Attribution (CC BY) license (https:/ / creativecommons.org/licenses/by/ $4.0 /)$.

\begin{abstract}
Motivation to study engineering in undergraduate study is of great importance to students. It encourages undergraduate students to enroll in an engineering program and continue their studies without dropping out. Male students enroll in engineering programs with large numbers compared to female students in many parts of the world. In Saudi Arabia, there were limited engineering programs for female students. In this research, the motivation to study engineering is studied and compared between male and female students in the College of Engineering at Prince Sultan University, the first private university in Saudi Arabia. The study was conducted through a detailed survey distributed to 41 male engineering management students and 45 female architectural engineering students. These students' performance and experience were considered and compared considering their gender to evaluate their persistence toward engineering study. According to the results obtained, the highest degree of the parents had a considerable effect on the selection of engineering major for male and female students. Most surveyed male and female students select an engineering major because of its positive impact on the community and its role in improving the way of life. Male students may differ in that they considered engineering in order to start their own business after graduation with a higher percentage compared to female students. There was a very limited role of the school in selecting engineering majors according to the surveyed male and female students. This role should be enhanced and utilized to encourage more female students to consider engineering majors in their college study.
\end{abstract}

Keywords: motivation; persistence; engineering education; gender

\section{Introduction}

Motivation can be defined as the procedure where the goal-oriented activity is activated and sustained. Researchers agreed to the one generic definition of motivation: a mental state that inspires the behavior and stimulates the desire to achieve the human mind's goals [1]. Motivation is also known as an academic engagement, which is considered the most powerful of all the influences that affect students' achievement. Academic motivation has been found positively connected to academic accomplishment and performance [1,2]. Researchers emphasize that academic motivation is the only factor that affects academic achievement directly, while the other factors indirectly affect academic performance through their effect on motivation [1]. Researchers generally agreed that motivation helps academic achievement and learning, as motivated students spend more time in their classes and tend to complete their studies, while the unmotivated students are likely to drop out of their studies [1,2].

Usually, motivation is affected by four factors of context, goal, temper, and instrument. To achieve their needs and goals, people acquire sufficient motivation. For students, motivation stimulates them to gain the required qualification in their careers [3]. Motivation defines the reasons for specific behavior. Motivated behaviors are energetic, oriented, and 
sustained. Therefore, motivating and engaging students in the learning process are among the most challenging tasks that parents and teachers have to deal with [2]. Accordingly, every educational organization is trying to discover the factors that motivate students to learn.

Engineers are vital to any succeeding society; therefore, effective learning and adequate training are critical in engineering education. Learning motivation among the students is crucial to the accomplishment of engineering education. Motivation is accepted to be an empowering cause for learning and academic achievement. In this manner, the goal of teaching academics is to investigate the factors that empower and motivate students to learn [4]. According to self-determination theory, there are three basic needs: the need for autonomy, the need for competence, and the need for relatedness. The main motivational factors identified by this theory were intrinsic motivation which is related to doing something for the sake of interest and pleasure; identified regulation, which relates the behavior to the goals or values; introjected regulation that represents the desire to attain appreciation from others; and external regulation that reflects the desire to be compensated for the activity. Self-determination theory identifies the last three factors as extrinsic motivation [5].

Kolmos et al. [6] used data from a survey covering all the enrolled students in Danish engineering education in autumn 2010. The study focused on some motivational factors: intrinsic motivation, good social motivation, financial motivation, parental motivation, and mentor motivation. The study identified that students' most important motivational factors in choosing engineering education were intrinsic motivation and good social motivation. Financial motivation came in the third position, followed by mentor motivation, while parental motivation was in the fifth position. In some studies conducted in Norway, Hong Kong, and Taiwan to investigate the motivational factors of studying engineering, the results were in line with the study of Kolmos et al. [6]. It was found that intrinsic factors have significant effects on choosing engineering education [7], but also extrinsic factors have the same effect. The most significant factors of intrinsic factors were "individual attitudes and expectations", while "pulling forces", "group pressure", and "learning approach" were the most prominent factors of extrinsic factors [4,8]. Another important factor in motivation is self-efficacy. Self-efficacy refers to what a person believes in her or his ability to perform a task. Self-efficacy has been verified to correlate with the intrinsic motivation and obligation to goal achievement. People with a high level of self-efficacy are expected to choose a high goal and achieve it [8]. In a study of the effect of instructional intervention strategies on motivating students in engineering education, it was found that instructional intervention strategies have a positive impact on self-efficacy and intrinsic motivation among the students [9].

The parents' influence on the career choice of the students was the concern of some other studies. Although parental motivation came in the fifth position in the study mentioned above [6], many studies reported that the parents' advice affects their students career choice [10-12]. In a study by Alpay et al. [13], the students' most motivating factor in studying engineering was their parents. In addition, parents and relatives who engaged in the construction industry were reported as reasons for joining the architecture study in Uganda [14].

Students' skills and abilities in math, science, and problem-solving were approved as the main motivating factors of students to join engineering studies [13,15]. In contrast, art and technical drawings beside math skills were the reasons for joining architecture study [14]. Enjoyment of hands-on work and variety in career options were identified as factors of motivations [13]. Financial security was highlighted as a motivation factor for engineering education in many studies [13-16].

For the factors of students' persistence in engineering education, Eris et al. [17] found that motivational factors influence students' persistence in engineering education. Skills of math and science, as well as mentor factor and parental factor, were positively correlated with students' persistence. Accordingly, the motivational factors influence the students' 
choice to join engineering education and impact their persistence and retention in their study. Abuelma'atti [18] reported that the main reasons for dropping the engineering study were poor skills of students, heavy teaching loads, insufficient educational commitment, and inadequate preparation for the transition to higher education level and lack of student advising and support.

Women represent around $50 \%$ of the population in any country. However, their representation in engineering studies of career is far less than $50 \%$. In most countries, women only occupy $10-25 \%$ of engineering education and professionals $[19,20]$. Many factors affect the huge difference in students' enrollment and achievement in relation to gender. Traditions concerning each gender role and cultural values significantly affect education field choice [21]. In addition, the deficiency of female role models in engineering education negatively affects female students' self-confidence $[13,22-24]$. The literature suggests that women and men are motivated by different factors to join engineering education. In the study of Kolmos et al. [6], intrinsic motivation, good social motivation, financial motivation, and parental motivation were more significant in males than in females. In contrast, mentor motivation was more significant in females rather than males. The same results of the mentors/teachers' effect of the females' choice were identified in other studies [25-27]. In other studies, it was found that male students are receiving more family support to join engineering than female students [22,28]. Atman et al. [24] mentioned that behavioral motivation was a significant factor for males. The behavioral factor means that students are motivated by the practical part of engineering, and they like to see it in reality. Gill at al. [29] showed that women are more influenced by human issues. Alpay et al. [13] reported that most male students chose the engineering study to invent something new, while the desire to make a difference in the world was a significant factor for the female students. Multiple studies showed that females more often chose engineering because they enjoy math and physics [13,29,30]. On the other hand, Sánchez-Barroso [7] reported that there was no statistically significant difference between males and females. In the Middle East, little research exists on evaluating engineering students' motivation, and almost no research exists on differences of motivation factors between males and females.

According to the Ministry of Higher Education in Saudi Arabia [31], there are more than 25 public universities in the Kingdom in 2013, holding more than 700,000 students; more than $50 \%$ of them are female. Table 1 represents the number of newly enrolled students in Saudi universities between 2010 and 2018 based on their gender. It is clear that before 2014, the number of enrolled male students was more than female students, even though the actual numbers are going down. This trend has been changed from 2015 onward. This observation is worth studying to meet the necessary preparation for future demand. The proportion of female students in the university under consideration is approximately $56 \%$ of the total member of students.

Table 1. New students' enrolment at the bachelor's level by gender.

\begin{tabular}{cccccccccc}
\hline Year & $\mathbf{2 0 1 0}$ & $\mathbf{2 0 1 1}$ & $\mathbf{2 0 1 2}$ & $\mathbf{2 0 1 3}$ & $\mathbf{2 0 1 4}$ & $\mathbf{2 0 1 5}$ & $\mathbf{2 0 1 6}$ & $\mathbf{2 0 1 7}$ & $\mathbf{2 0 1 8}$ \\
\hline Male & 114,222 & 137,866 & 149,129 & 183,762 & 162,492 & 138,936 & 154,868 & 155,082 & 103,944 \\
Female & 113,503 & 124,166 & 139,846 & 169,079 & 164,363 & 154,814 & 161,425 & 154,368 & 119,193 \\
Total & 227,725 & 262,032 & 288,975 & 352,841 & 326,855 & 293,750 & 316,293 & 309,450 & 223,137 \\
\hline
\end{tabular}

The data provided from the Ministry of Higher Education show that the number of engineering, manufacturing, and construction programs offered for female students is 12 at the bachelor's level compared to 114 for male students. Only 30,000 female students have been enrolled in such fields in the years 2008-2012 compared to almost 296,000 males, i.e., a ratio of nearly 1 to 10 , with an average of $1 \%$ annual increase. Furthermore, throughout the years 2007-2011, only 4000 female engineers have graduated from Saudi universities versus almost 66,000 male engineers [32]. There are various promising signs of the possible increase in interest and enrollment of Saudi females in engineering. The data showed an increase in universities that offers engineering programs to females in the last three 
years [31]. Recent statistics also showed that $80 \%$ of female students in Saudi Arabia are interested in engineering [32].

Therefore, the main focus of this study was to investigate on the impact of students' gender on their motivation and persistence to study engineering at Prince Sultan University, Saudi Arabia. A group of 41 male engineering management students and 45 female architectural engineering students was surveyed. The survey investigated their motivation factors to enroll in engineering programs such as the role of the family in the students selection of their major, the level of education of the parents, the vision of the students to the engineering profession in terms of its monetary value, its contribution to the enhancement of life and community, and how prestigious the profession is. These students' performance and experience were also considered and compared according to students' gender to evaluate their persistence toward engineering study.

\section{Materials and Methods}

\subsection{Participants}

The data were collected using a questionnaire survey distributed to third, fourth, and fifth-year female and male students of the College of Engineering at Prince Sultan University in Riyadh, Saudi Arabia in 2019, who were selected as a sample to be surveyed, forming a sample of 86 cases; 41 male engineering management students and 45 female architectural engineering students participated in the survey, which according to central limit theorem the distribution of the sample means will be approximately normally distributed. The majority of these students finished more than 60 credit hours in the program.

\subsection{Measures}

The survey's primary purpose was to investigate on the impact of students' gender on their motivation and persistence to study engineering. The study utilizes the quantitative data, which were statistically analyzed. The variables of the questionnaire were measured using a checklist and Likert scale measurement. The questionnaire was divided into two parts, each with various questions to investigate the factors that motivate students to study engineering and factors that may affect their persistence to continue their studies. The whole survey was developed by Ibrahim et al. [16].

\subsection{Procedure}

A detailed survey was conducted to determine the factors that motivate students to study engineering and compare male and female students in their response and perception. The literature revealed that questions randomization is a good practice to prevent bias in testing concepts and topics. Accordingly, for the type of motivation, the questions of this survey have been randomized. The survey included questions about the family's role in the students' selection of their major and whether one of the parents or both are engineers. In addition, the parents' level of education was questioned to know if there is a relationship between the highest degree obtained by at least one of the parents and the selection of engineering for both male and female students. Moreover, the survey included some questions regarding the students' vision to the engineering profession in terms of its monetary value, its contribution to enhancing life and community, and how prestigious the profession is. The relationship of the students' level in introductory courses in high school that have relevance to engineering studies such as physics, mathematics, computer science, crafts, and fine arts is considered through some questions in the survey.

The second part of the survey considers the factors that can affect the progress of the male and female students and their commitment to continue their engineering studies. Among these factors, the survey examines the student's cumulative Grade Point Average, GPA, the best favorable subjects and hardest/challenging courses in their first year at College of Engineering, students' expectations on their performance during their study, their classes' attendance rate, and overall evaluation of their study experience at the College of Engineering. 


\subsection{Data Analysis}

The information gathered from the questionnaire was examined using SPSS statistical tool analysis and Minitab [33].

Opinions of students toward their motives for studying engineering were presented in Figures 1 and 2. Based on the findings, as shown in Figure 1, the majority of the students thought that their parents do not intervene with their selection toward studying engineering $(n=37)$, while students were also advised and led for the selection of engineering $(\mathrm{n}=35)$. The majority of the students mentioned that their family members had not studied engineering before their admission in the engineering university $(n=35)$. "Graduate from a college" was the level of education for most parents $(n=45)$. Precisely, Figure 1 has shown mixed findings related to the motives toward engineering. When students were asked about the role of the family in selecting engineering, most female and male students mentioned that their parents did not intervene with their selection toward engineering. The majority of the female students already have an engineer in their family $(n=17)$. A total of 45 students' parents have graduated from a college (Male students $=20$; Female $=25$ ).
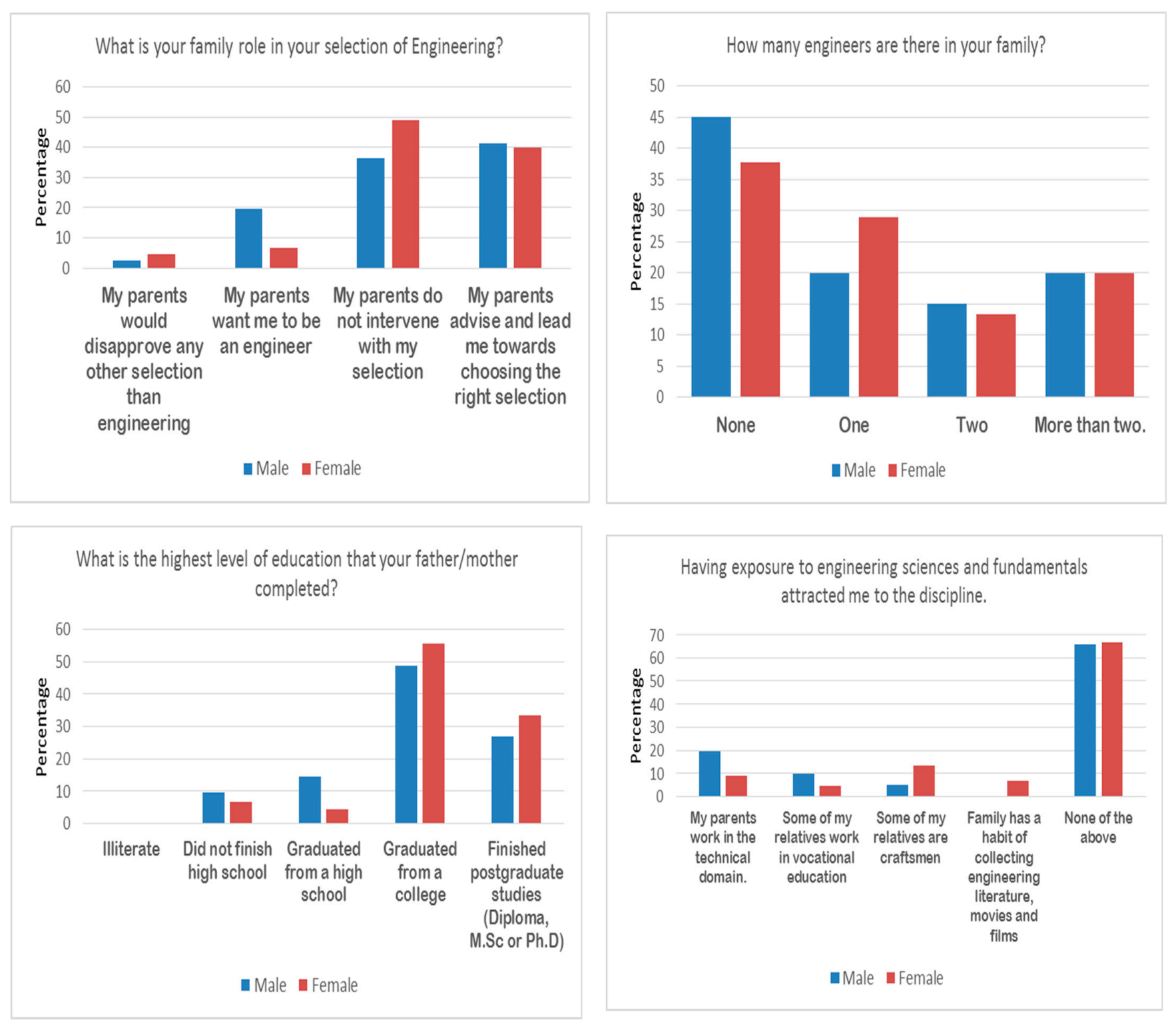

Figure 1. Motive to study engineering (parental motivational factor). 

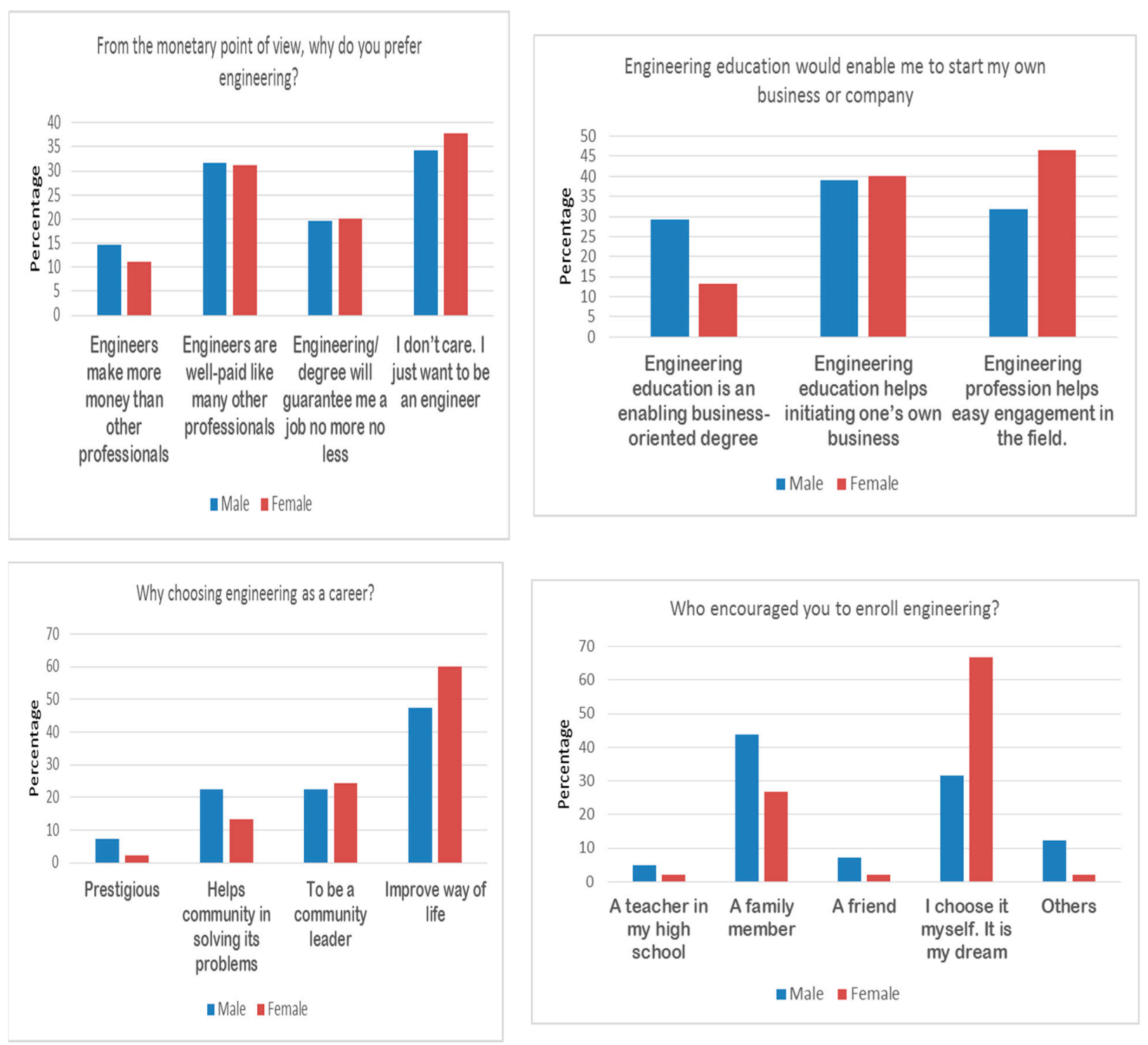

Figure 2. Motive to study engineering (financial, intrinsic, and mentor motivational factors).

Undertaking the monetary stance, as shown in Figure 2, most students thought engineers are well-paid, similar to many other professionals $(n=27)$. Similarly, students thought engineering education helps to initiate their own business and easy interaction in the field ( $n=34)$, respectively. In addition, engineering was selected as it improves lifestyle ( $n=46)$.

The majority of the students want to be engineers when they were asked whether the selection was based on monetary aspects (Male students $=14$; Female $=17$ ). According to findings, most of the students have mentioned that the engineering profession assists in easy engagement in the field (Male students $=13$; Female $=21$ ). Improvement in the lifestyle was one of the core reasons for selecting engineering as a career (Male students = 19; Female $=27$ ). Thirty female students quoted engineering as a dream, whereas 18 male students mentioned that their family member encouraged them to enroll in engineering.

For the persistence factors, as shown in Figure 3, the results showed that the majority of the students were satisfied with the classroom and teaching facilities $(n=43)$, laboratories $(\mathrm{n}=32)$, computer lab $(\mathrm{n}=46)$, and traditional library $(\mathrm{n}=29)$ when studying engineering in university. None of the students visited the library during the 1st semester $(n=31)$. 

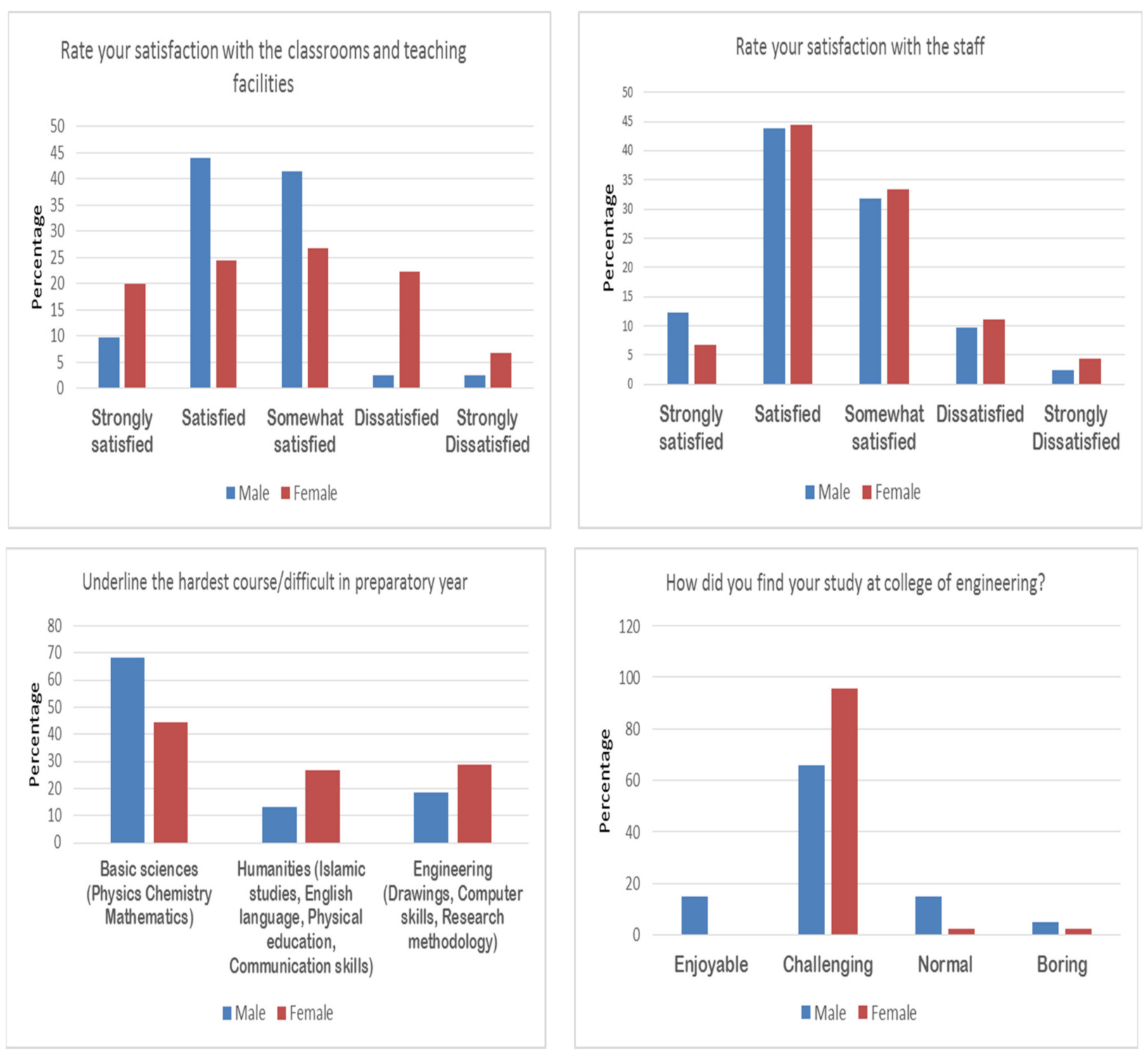

Figure 3. Persistence of students.

Figure 3 presents the satisfaction of both male and female students toward engineering. The majority of the students were satisfied with the classroom and teaching facilities (Male students $=18$; Female $=11$ ), somewhat satisfied with the laboratories (Male students $=12$; Female $=18$ ), satisfied with the computer lab (Male students $=12$; Female $=15$ ); somewhat satisfied with the traditional library (Male students $=10$; Female $=21$ ), somewhat satisfied with the electronic library (Male students $=19$; Female $=21$ ), satisfied with the staff (Male students $=18$; Female $=20$ ), and somewhat satisfied with the style of building and landscaping (Male students $=11$; Female $=15$ ). Surprisingly, the majority of the participants never visited the library during the 1 st semester (Male students $=41$; Female $=45$ ) and acquired information from search engines such as Google and Yahoo for doing scientific research (Male students $=30$; Female $=31$ ).

The students were asked to rate their capability and performance during high school in the following subjects: English language, computer science, mathematics, physics, fine arts, and crafts. The results of this section are shown in Table 2. It was observed that female students believe that they are more capable in all disciplines than male students, especially in fine arts and crafts. This may be attributed to the nature of female students' study, which is architecture engineering compared to male students who study engineering 
management. Therefore, female students selected this discipline according to their high capability and/or interest.

Table 2. Students capability in different subjects: English language, Mathematics, Physics, Computer Science, Fine Art, and Craft (M: Male and F: Female).

\begin{tabular}{|c|c|c|c|c|c|c|c|c|c|c|c|c|}
\hline \multirow{3}{*}{$\begin{array}{l}\text { Capability } \\
\text { Level }\end{array}$} & \multicolumn{12}{|c|}{ Percentage of Students Rating Their Capability in Different Subjects } \\
\hline & \multicolumn{2}{|c|}{$\begin{array}{c}\text { English } \\
\text { Language }\end{array}$} & \multicolumn{2}{|c|}{ Mathematics } & \multicolumn{2}{|c|}{ Physics } & \multicolumn{2}{|c|}{$\begin{array}{c}\text { Computer } \\
\text { Science }\end{array}$} & \multicolumn{2}{|c|}{ Fine Art } & \multicolumn{2}{|c|}{ Craft } \\
\hline & $\mathbf{M}$ & $\mathbf{F}$ & $\mathbf{M}$ & F & $\mathbf{M}$ & F & $\mathbf{M}$ & $\mathbf{F}$ & $\mathbf{M}$ & $\mathbf{F}$ & $\mathbf{M}$ & $\mathbf{F}$ \\
\hline Excellent & 29.3 & 68.9 & 43.9 & 62.3 & 26.8 & 37.8 & 31.9 & 42.3 & 25 & 46.7 & 17.5 & 51.1 \\
\hline Very good & 34.1 & 8.9 & 26.8 & 24.4 & 34.2 & 33.3 & 9.8 & 24.4 & 12.5 & 31.1 & 17.5 & 28.9 \\
\hline Good & 22 & 22.2 & 29.3 & 11.1 & 36.6 & 22.2 & 43.9 & 24.4 & 30 & 13.3 & 45 & 17. 8 \\
\hline Poor & 12.2 & 0 & 0 & 2.2 & 2.4 & 6.7 & 9.8 & 8.9 & 25 & 6.7 & 5 & 0 \\
\hline Very poor & 2.4 & 0 & 0 & 0 & 0 & 0 & 4.6 & 0 & 7.5 & 2.2 & 15 & 2.2 \\
\hline
\end{tabular}

On the other hand, the female students' rating of their mathematics and physics capability was a bit higher than the rating of male students to these subjects, but without a big difference as obtained in fine arts and crafts. Students' skills and abilities in math, science, and problem-solving were approved as the main factor for motivating students to join engineering studies $[13,15]$. In contrast, art and technical drawing beside math skills were the reasons for joining the architecture study [14].

Each student was asked to provide details about his/her GPA. This question's responses enable students' classification in terms of their GPA into different categories, as shown in Table 3.

Table 3. Students' Grade Point Average (GPA, by the percentage of students).

\begin{tabular}{ccc}
\hline GPA & Male & Female \\
\hline Less than 2.0 & $15 \%$ & $2 \%$ \\
$2.0-2.5$ & $32 \%$ & $11 \%$ \\
$2.5-3.0$ & $34 \%$ & $11 \%$ \\
$3.0-3.5$ & $12 \%$ & $29 \%$ \\
$3.5-4.0$ & $7 \%$ & $47 \%$ \\
\hline
\end{tabular}

As shown in Table 3, female students have a higher GPA compared to male students. Almost $76 \%$ have a GPA of more than 3.0 out of 4.0 compared to only $19 \%$ of male students. This result indicates the excellent performance of female students during their study of architecture engineering. Multiple studies showed that females were more significant in choosing engineering because they enjoy math and physics [13,28,29]. Moreover, Eris et al. [17] found that math and science skills were positively correlated with students persistence. The students were given five categories and were asked to rate which one of these categories is the most favorite subject in the preparatory year. These categories were basic sciences, humanities, engineering, management, and lab work. The descriptive statistics indicated that more than $40 \%$ of the students agreed that engineering courses are the most enjoyable courses, followed by basic sciences courses.

Finally, Pearson correlation analysis was used for determining the relationship between motivation and persistence toward studying engineering with respect to gender. The percentage of responses for each question of each set of the sample (male and female students) were recorded. It was assumed that students' answers are continuous variables, and a 95\% confidence level is tested. Results are shown in Figures 4 and 5, Tables 4 and 5, and Tables A1 and A2 in the Appendix A. The findings have indicated a strong and positive correlation between family role in the selection of engineering; having engineers in the family; parents' highest level of education; exposure to engineering sciences and fundamentals; and the benefit of engineering in starting a business or a company. All these correlations 
were significant at a $5 \%$ level of significance. The results also indicate that the correlation, $r$, between male and female students' answers for motivation to study engineering was at 0.754 , while the correlation for persistence to study engineering was at 0.787 . The $p$-value was at zero, which indicates there is a strong relationship between male and female answers. The major conclusion is that there are no significant differences between their answers, but more correlation was noticed regarding the persistence to study engineering, which means that male and female engineering students have the same perceptions of their learning environment.

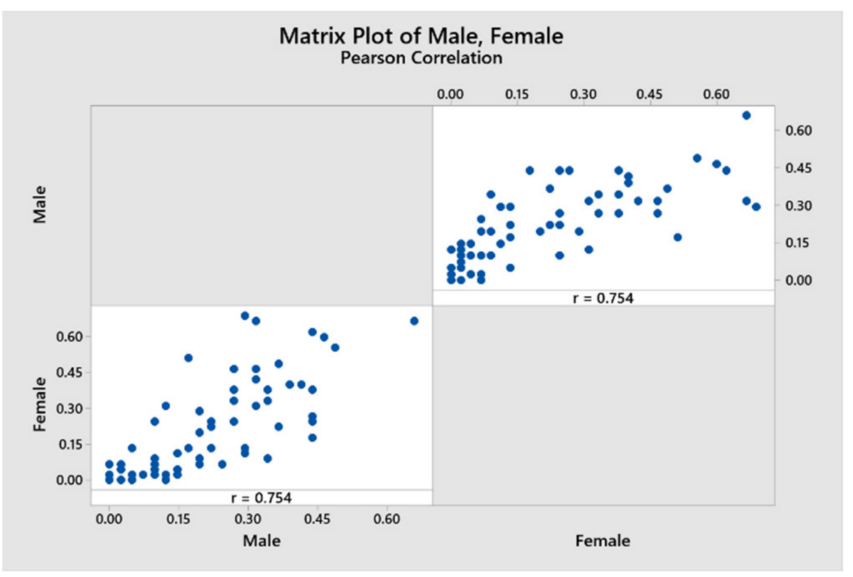

Figure 4. Correlation of motivation to study engineering for male and female students.

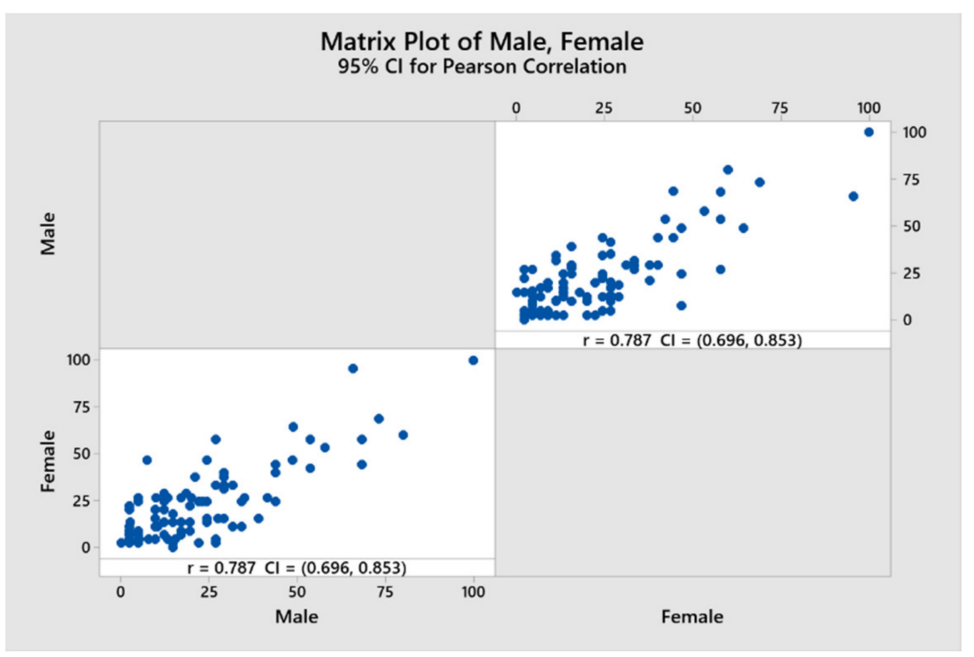

Figure 5. Correlation of persistence to study engineering for male and female students.

Table 4. Pairwise Pearson correlations for motivation to study engineering for male and female students.

\begin{tabular}{ccccc}
\hline Sample 1 & Sample 2 & Correlation & $\mathbf{9 5 \%}$ CI for $\boldsymbol{\rho}$ & $\boldsymbol{p}$-Value \\
\hline Female & Male & 0.754 & $(0.625,0.843)$ & 0.000 \\
\hline
\end{tabular}

Table 5. Pairwise Pearson correlations for persistence to study engineering for male and female students.

\begin{tabular}{ccccc}
\hline Sample 1 & Sample 2 & Correlation & $\mathbf{9 5 \%}$ CI for $\boldsymbol{\rho}$ & $p$-Value \\
\hline Female & Male & 0.787 & $(0.696,0.853)$ & 0.000 \\
\hline
\end{tabular}




\section{Discussion}

Profession payments, the prestigious nature of the profession, and having one's own business are the motivation parameters of significance in the area of personal perspective. Financial security was highlighted as a motivation factor for engineering education in many studies [13-15]. No visible association or pattern has been identified between having architectures or engineers in the family with students' selection toward major in architecture or engineering. It was identified that parents possessing a postgraduate or undergraduate degree affect the major of students. Parents possessing a postgraduate or undergraduate degree have an influence on the major subject of choice of the student. Family members are the most substantial influential persons who recommended or suggested engineering or architecture. This observation is in line with the results of many studies that reported that the parents' advice affects their children's career choice [10,11]. The majority of students have high self-confidence in physics, computer sciences, and physics that opt to major in architecture or engineering. In engineering education, the performance was affected by students attending classes with a very effective rate in subject matter handled, preference, subject attraction, and abilities. Based on their responses, it has been observed that students were somehow pressurized from the weekly timetable. A high-school life might show changes in campus life. On the contrary, the opinions of students might be undertaken to develop the timetable. The preparatory year has been considered enjoyable, challenging, and agreeable by more than half of the tested sample at the university. Most of the students were satisfied with the performance, attitude, and conduct of employees, student affairs deanship, and educational facilities. A high extent of students were performing effectively and anticipating high grades in their preparatory year. The extent of students deciding to study architecture or engineering will be identified via monitoring the same group of students in the upcoming surveys. The causes of fallouts must be examined at that time.

There might be visibly some disparity between educators' objectives and those of students evident from such findings if educators agree in regard to preferring their students to take a constructivist approach to learning in the Faculty of Engineering. Findings have indicated that students were extrinsically motivated. In this regard, a question arises as to whether the educators' objective should be to stimulate success for fulfilling the need of students for self-esteem in summative assessments. In addition, findings have indicated that students were encouraged by a want for learning and for self-actualization. Such evidence refers to what we must pursue to establish intrinsic motivation in undergraduate study.

The significance of the role of lecturers should be emphasized to motivate students. It is also visible that radically innovative pedagogies pursuing in-depth learning from students need incremental implementation, which may not instantly be confident to realize their own learning objectives and act as in-depth learners. A greater proclivity has been explained toward extrinsic motivation where surface learning brings about recognition.

The findings of this study offer an observation of the factors that influence students' persistence in engineering. Emphasizing students in engineering facilitates the findings to be generalized to other settings. The preliminary results have recommended that financial motivation is one of the most vital factors in persistence, even though other researchers did not find it to be significant.

Knowledge is characterized by distinctive characters and impetus, particularly for engineering disciplines who face an academic transition. The work's objective was to build apprehension among students by the way students could acquire the elements of motivation during the transition of multiple timescales, aiming to resolve the hindrances. During the evaluation of the problem solving from the students of engineering who have been enrolled in the first year, it was revealed that their perception regarding the foreseeable future was correlated positively on the issue of exploring the hidden elements of problem and time that were needed to complete and resolve the issue. According to these insights, the students' goals work as an impetus and motivate them to implement solution-oriented practices. Moreover, students have implemented these solution-oriented practices that 
have been observed to have more significant improvement in their preliminary courses of engineering. The study's findings have discovered another aspect of the influence of motivation in students' academic success. Two aspects were analyzed that provided insights regarding the time-intensity of motivation among students and its role in enticing solution-oriented behavior and practices. From the analysis, it can be concluded that the rationales about the role of motivation in the discipline of engineering for deriving the solution-oriented approach and learning were not adequate. From the academic experience of college, the element of supporting tenacity can be inculcated in the students of engineering. Moreover, participants also indicated that it was a demonstration of persistence when students became able to get assistance in understanding a concept. However, creating an environment that is abundant with the individuals who have the same thoughts was considered a means to develop a support mechanism formed with the groups of students and peers. Interaction with the members of faculty also played an effective role to resolve the hurdles that were being encountered during completing homework and other programs that were aimed to increase students' engagement. Additionally, the students were of the view that the key to achieving higher ranking was exceptional hardworking. These results are in line with previous studies that concluded that higher grades and marks were the decisive indicators to predict the number of students who could complete their study programs [34-36].

Amid the recruitment process in engineering courses, the academic standings of education during high school provide foresight about the level of persistence. According to Palmer et al. (2011) [37], vigorous preparation during high school had the supporting role for the students of engineering programs. The research's participants had consent and indicated that robust preparation during high school had an effective role in making the process of transition less complicated to enter engineering courses. Furthermore, the participants made it clear that higher-ranking performance during high school was also the positive and supportive element that paved the way for convenient admission process in the courses. These results are compatible with the findings of Astin and Oseguera (2005) [38], who reported that the grade point averages of high school helped predict students' tendency to complete the degree. Similarly, Horn and Kajaku (2001) [39] revealed that students who had been facing hurdles in apprehending curriculum could be predicted to remain in college.

The above-stated fact exhibited that facing high school challenges and attaining higher marks or grades increased the chances of continuing engineering programs. Students also explained that intrinsic motivation provided satisfaction to work industriously, get high marks, and cope with the challenges. Getting an " $\mathrm{A}$ " grade or solving the complex nature of problems were associated with more pleasure. Apart from these fields, academic conduct was not described as considerable, as students perceived that getting high marks and passing was only possible through working hard. However, the higher the efforts to pass the exams would lead to higher grades in exams that will positively impact academic performance. Many researchers have found that there is a role of academic and social integration in determining students' persistence [40].

The concept of social activities was defined as the approach adopted by the individuals for connecting from all the parts and personals of university. This explanation of social activities was conceded by Tinto and Riemer (1998) [41], who researched the way beneficial engagement worked in retaining knowledge at an institutional setting. On the other hand, numerous studies have asserted that participation at the time of activities and engagement could be merely possible if the homework is finalized. Therefore, time management was emphasized as an integral element to be taught before initiating social activities. Social experience provided students with a way to reduce stress as well as more chances to create and indulge in the social and academic activities of life. Moreover, it is also suggested that activities were the central element in maintaining equilibrium for outperforming in engineering courses. 


\section{Conclusions}

In order to study the motivation and persistence of male and female students in their undergraduate study in engineering programs in Saudi Arabia, a detailed survey was distributed to 41 male engineering management students and 45 female architectural engineering students at the College of Engineering at Prince Sultan University. The survey questioned many factors that may affect the motivation of students to study engineering such as the role of the family in the students' selection of their major, the level of education of the parents, the vision of the students to the engineering profession in terms of its monetary value, its contribution to the enhancement of life and community, and how prestigious the profession is. Moreover, the survey questioned the students' ratings to their high school courses' capability that have relevance to engineering studies such as physics, mathematics, computer science, crafts, and fine arts. The study also investigated the students' experience during the first years in the engineering programs and their evaluation of their performance in the light of their GPA and their satisfaction. Correlation between male and female students' motivation to study engineering was at 0.754 , while the correlation for persistence to study engineering was at 0.787 . The $p$-value was at zero, which indicates there is a strong relationship between male and female answers.

According to the results obtained, the role of the parents in selecting an engineering major for the students is mainly advising, and in many cases, parents do not intervene in the selection, especially for female students. The highest degree of the parents played an important role in motivating students to major in the engineering program, especially for female students. The percentage of surveyed engineering students whose parents have at least a college degree was $76 \%$ and $85 \%$ for male and female students, respectively. Having engineers in the family played a fair role in the students' selection of engineering majors. Around $45 \%$ and $37 \%$ of male and female students, respectively, chose engineering majors who have no engineers in their families. There is a very limited role of the school in selecting engineering majors for both male and female students. This role can be significantly enhanced through efficient collaboration between high schools and colleges of engineering in the surrounding community through school visits and awareness sessions and events.

Most male and female students have selected the engineering major because of its positive impact on the community and its role in improving the way of life. Male and female engineering students share similar visions to the engineering profession in terms of the monetary value after graduation. However, more male students consider engineering in order to start their own business after graduation, compared to female students.

Female students rated their capability in high school math, physics, computer sciences, fine arts, and craft better than male students. In addition, female students earned a higher GPA in engineering programs compared to male students. However, more female students rated their experience during the first years of engineering study as challenging, despite getting a high GPA.

The results of this study should encourage offering more engineering programs to female students in Saudi Arabia as they are well motivated and capable, which will maximize their role in serving the community and enhancing the quality of life.

It is worth mentioning that the results of this study were based on the survey distributed to engineering management male students and architecture engineering female students in a private university in Saudi Arabia. Male and female students surveyed in this study are engineering students who are enrolled to the same college through the same enrollment criteria. However, they belong to different programs, which may affect the study results. The number of students surveyed in this study is not large enough to generalize the survey results to the entire population of engineering students in the kingdom and in the world. The study will be extended to include more participants from male and female students in other engineering majors from other universities in Saudi Arabia to investigate about the variance in motivation and persistence to study engineering in the Kingdom. 
Author Contributions: Conceptualization, W.L., A.A. (Amal Abdelsattar), Y.I. and A.A. (Abdelhakim Abdelhadi); Data curation, W.L., A.A. (Amal Abdelsattar), Y.I. and A.A. (Abdelhakim Abdelhadi); Formal analysis, W.L. and A.A. (Abdelhakim Abdelhadi); Funding acquisition, W.L.; Investigation, A.A. (Abdelhakim Abdelhadi); Methodology, A.A. (Amal Abdelsattar) and Y.I.; Project administration, A.A. (Amal Abdelsattar) and A.A. (Abdelhakim Abdelhadi); Software, W.L.; Supervision, W.L. and Y.I.; Writing-original draft, W.L., A.A. (Amal Abdelsattar), Y.I. and A.A. (Abdelhakim Abdelhadi). All authors have read and agreed to the published version of the manuscript.

Funding: This research is funded by Prince Sultan University: 2021.

Institutional Review Board Statement: Not applicable.

Informed Consent Statement: Not applicable.

Data Availability Statement: The data presented in this study are available on request from the corresponding author.

Acknowledgments: The presented work was funded by Prince Sultan University, Riyadh, KSA. The financial support is gratefully acknowledged.

Conflicts of Interest: The authors declare no conflict of interest.

\section{Appendix A}

Table A1. Correlation analysis between motivation with respect to gender.

\begin{tabular}{|c|c|c|c|}
\hline Factors & & Correlation Analysis & $p$-Value \\
\hline \multicolumn{4}{|c|}{ What is the influence of your family in your selection of engineering? (parental motivation) } \\
\hline & $\begin{array}{l}\text { My parents would disapprove of any other selection than engineering } \\
\text { My parents want me to be an engineer } \\
\text { My parents do not intervene with my selection } \\
\text { My parents advise and lead me toward choosing the right selection }\end{array}$ & 0.898 & $<0.000$ \\
\hline \multicolumn{4}{|c|}{ How many engineers are there in your family? (parental motivation) } \\
\hline & $\begin{array}{l}\text { None } \\
\text { One } \\
\text { Two } \\
\text { More than two }\end{array}$ & 0.971 & $<0.000$ \\
\hline \multicolumn{4}{|c|}{ What is the highest level of education that your father/mother completed? (parental motivation) } \\
\hline & $\begin{array}{l}\text { Illiterate } \\
\text { Did not finish high school } \\
\text { Graduated from a high school } \\
\text { Graduated from a college } \\
\text { Finished postgraduate studies (Diploma, M.Sc or Ph.D) }\end{array}$ & 0.950 & $<0.000$ \\
\hline \multicolumn{4}{|c|}{ Having exposure to engineering sciences and fundamentals attracted me to the discipline (parental motivation) } \\
\hline & $\begin{array}{l}\text { My parents work in the technical domain } \\
\text { Some of my relatives work in vocational education } \\
\text { Some of my relatives are craftsmen } \\
\text { The family has a habit of collecting engineering literature, movies, and films } \\
\text { None of the above }\end{array}$ & 0.986 & $<0.000$ \\
\hline \multicolumn{4}{|c|}{ From the monetary point of view, why do you prefer engineering? (financial motivation) } \\
\hline & $\begin{array}{l}\text { Engineers make more money than other professionals } \\
\text { Engineers are well-paid, similar to many other professionals } \\
\text { Engineering/degree will guarantee me a job, no more no less } \\
\text { I don't care. I just want to be an engineer }\end{array}$ & 0.544 & $>0.000$ \\
\hline \multicolumn{4}{|c|}{ Engineering education would enable me to start my own business or company (financial motivation) } \\
\hline & $\begin{array}{l}\text { Engineering education is an enabling business-oriented degree } \\
\text { Engineering education helps to initiate one's own business } \\
\text { Engineering profession helps easy engagement in the field }\end{array}$ & 0.976 & $<0.000$ \\
\hline
\end{tabular}


Table A1. Cont.

\begin{tabular}{lc}
\hline Factors & Correlation Analysis \\
\hline Why choosing engineering as a career? (intrinsic motivation) & \\
\hline Prestigious & 0.698 \\
Helps the community in solving its problems & $>0.000$ \\
To be a community leader & \\
Improve the way of life & \\
\hline Who encouraged you to enroll in engineering? (mentor motivation) & 0.546 \\
\hline A teacher in my high school & $>0.000$ \\
A family member & \\
A friend & \\
Otheose it myself. It is my dream & \\
\hline
\end{tabular}

Table A2. Correlation analysis between persistence with respect to gender.

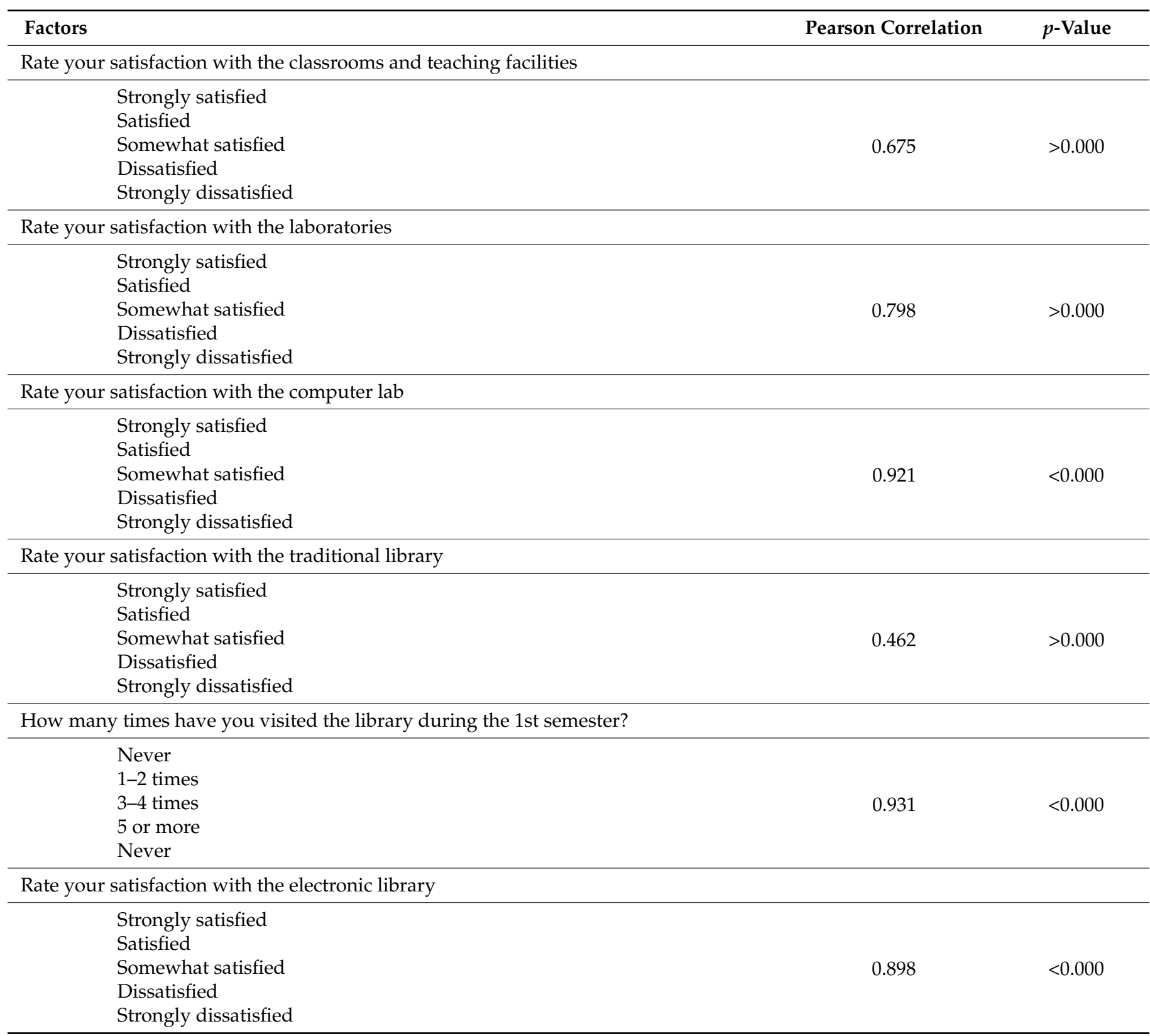


Table A2. Cont.

\begin{tabular}{|c|c|c|c|}
\hline Factors & & Pearson Correlation & $p$-Value \\
\hline \multicolumn{4}{|c|}{ How many times have you visited the library website during the 1st semester? } \\
\hline & $\begin{array}{l}\text { Never } \\
1-2 \text { times } \\
3-4 \text { times } \\
5 \text { or more }\end{array}$ & 0.886 & $<0.000$ \\
\hline \multicolumn{4}{|c|}{ To do scientific research, from where you get your information } \\
\hline & $\begin{array}{l}\text { Books, journals, and periodicals } \\
\text { University library website } \\
\text { Search engines, such as Google, yahoo etc. } \\
\text { Other websites, please specify }\end{array}$ & 0.986 & $<0.000$ \\
\hline \multicolumn{4}{|c|}{ Rate your satisfaction with the staff } \\
\hline & $\begin{array}{l}\text { Strongly satisfied } \\
\text { Satisfied } \\
\text { Somewhat satisfied } \\
\text { Dissatisfied } \\
\text { Strongly dissatisfied }\end{array}$ & 0.984 & $<0.000$ \\
\hline \multicolumn{4}{|c|}{ Rate your satisfaction with the style of buildings and landscaping } \\
\hline & $\begin{array}{l}\text { Strongly satisfied } \\
\text { Satisfied } \\
\text { Somewhat satisfied } \\
\text { Dissatisfied } \\
\text { Strongly dissatisfied }\end{array}$ & -0.289 & $>0.000$ \\
\hline \multicolumn{4}{|c|}{ What is the range of your current GPA? } \\
\hline & $\begin{array}{l}\text { Less than } 2.0 \\
\text { Between } 2.0-2.5 \\
\text { Between } 2.5-3.0 \\
\text { Between } 3.0-3.5 \\
\text { Between } 3.5-4.0\end{array}$ & -0.628 & $>0.000$ \\
\hline \multicolumn{4}{|c|}{ Underline the most THREE favorable subjects for you in the preparatory year } \\
\hline & $\begin{array}{l}\text { Basic sciences (Physics, Chemistry, Mathematics) } \\
\text { Humanities (Islamic studies, English language, Physical education } \\
\text { Communication skills) } \\
\text { Engineering (Drawings, Computer Skills, Research methodology, design, } \\
\text { analysis) } \\
\text { Management course } \\
\text { Lab work }\end{array}$ & 0.877 & $<0.000$ \\
\hline \multicolumn{4}{|c|}{ Underline the most challenging course in the preparatory year } \\
\hline & $\begin{array}{l}\text { Basic sciences (Physics, Chemistry, Mathematics) } \\
\text { Humanities (Islamic studies, English language, Physical education, } \\
\text { Communication skills) } \\
\text { Engineering (Drawings, Computer skills, Research methodology) }\end{array}$ & 0.999 & $<0.000$ \\
\hline \multicolumn{4}{|c|}{ Based on your abilities, what do you think about your expected performance in the College of Engineering? } \\
\hline & $\begin{array}{l}\text { I will find no problem at all } \\
\text { I'm sure I will perform well, although engineering is difficult } \\
\text { I'm not sure } \\
\text { I expect much difficulties, let's wait and see if I can bear it or not }\end{array}$ & 0.921 & $<0.000$ \\
\hline \multicolumn{4}{|c|}{ How overloaded do you feel in your study compared to what you expected? } \\
\hline & $\begin{array}{l}\text { Less than I expected } \\
\text { Exactly as I expected } \\
\text { Stressed } \\
\text { I cannot bear it }\end{array}$ & 0.683 & $>0.000$ \\
\hline
\end{tabular}


Table A2. Cont.

\begin{tabular}{cc}
\hline Factors & Pearson Correlation \\
\hline When were you enrolled to PSU? & \\
\hline $2013 / 2014$ & 0.457 \\
$2014 / 2015$ & $>0.000$ \\
$2015 / 2016$ & \\
$2016 / 2017$ & \\
$2017 / 2018$ & \\
\hline
\end{tabular}

\section{References}

1. Yukseloglu, S.M.; Karaguven, M.H. Academic Motivation Levels of Technical High School Students. Procedia Soc. Behav. Sci. 2013, 106, 282-288.

2. Hakan, K.; Münire, E. Academic Motivation: Gender, Domain and Grade Differences. Procedia Soc. Behav. Sci. 2014, 143, 708-715. [CrossRef]

3. Steinmayr, R.; Weidinger, A.F.; Schwinger, M.; Spinath, B. The Importance of Students' Motivation for Their Academic Achievement-Replicating and Extending Previous Findings. Front. Psychol. 2019, 10, 1730. [CrossRef]

4. Law, K.M.Y.; Sandnes, F.E.; Huang, Y. A comparative study of learning motivation among engineering students in South East Asia and beyond. Int. J. Eng. Educ. 2010, 25, 144-151.

5. Catz, B.; Sabag, N.; Gero, A. Problem Based Learning and Students' Motivation: The Case of an Electronics Laboratory Course. Int. J. Eng. Educ. 2018, 34, 1838-1847.

6. Kolmos, A.; Mejlgaard, N.; Haase, S.; Holgaard, J.E. Motivational Factors, Gender and Engineering Education. Eur. J. Eng. Educ. 2013, 38, 340-358. [CrossRef]

7. Sánchez-Barroso, G.; González-Domínguez, J.; García-Sanz-Calcedo, J.; Zamora-Polo, F. Analysis of Learning Motivation in Industrial Engineering Teaching in University of Extremadura (Spain). Sustainability 2020, 12, 4987. [CrossRef]

8. Law, K.; Chuah, K. What Motivates Engineering Students? A Study in Taiwan. Int. J. Eng. Educ. 2009, 25, 1068-1074.

9. Lim, G.; Chua, K.S.; Wee, K.Y.U.N. Effects of Instructional Intervention Strategies on Students at Risk in Engineering Education. Int. J. Eng. Educ. 2003, 19, 525-531.

10. Whiston, S.C.; Keller, B.K. The influences of the family of origin on career development: A review and analysis. Couns. Psychol. 2004, 32, 493-568. [CrossRef]

11. Reis, A.; Patrocínio, C.; Lourtie, P. Gender issues in attracting students to science, technology, and engineering higher education. In Proceedings of the SEFI 40th Annual Conference, Thessaloniki, Greece, 23-26 September 2012.

12. Bandura, A.; Barbaranelli, C.; Caprara, G.V.; Pastorelli, C. Self-Efficacy Beliefs as Shapers of Children's Aspirations and Career Trajectories. Child Dev. 2001, 72, 187-206. [CrossRef]

13. Alpay, E.; Ahearn, A.L.; Graham, R.H.; Bull, A.M.J. Student Enthusiasm for Engineering: Charting Changes in Student Aspirations and Motivation. Eur. J. Eng. Educ. 2008, 33, 573-585. [CrossRef]

14. Olweny, M.R.O. Students' Motivation for Architecture Education in Uganda. Front. Archit. Res. 2017, 6, 308-317. [CrossRef]

15. Stevens, R.; Amos, D.; Garrison, L.; Jocuns, A. Engineering as lifestyle and a meritocracy of difficulty: Two pervasive beliefs among engineering students and their possible effects. In Proceedings of the 2007 American Society for Engineering Education Annual Conference, Honolulu, Hawaii, 24 August 2007.

16. Ibrahim, Y.E.; Salman, A.; El-Brawany, M.; Abdel-Magid, I.M. Motivation and Persistence in Engineering Education: A Case Study at King Faisal University, Dammam Campus, KSA. In Proceedings of the 1st International Conference on Engineering Education (ICEE2009), Engineering and Technology Education: Challenges of Globalization, Al-Madina, Saudi Arabia, 6-17 May 2009.

17. Eris, O.; Chachra, D.; Chen, H.L.; Sheppard, S.; Ludlow, L.; Rosca, C.; Bailey, T.; Toye, G. Outcomes of a Longitudinal Administration of the Persistence in Engineering Survey. J. Eng. Educ. 2010, 99, 371-395. [CrossRef]

18. Abuelma'atti, M. Engineering education in Saudi Arabia: Problems and solutions. In Proceedings of the Fourth Saudi Technical Conference and Exhibition, Riyadh, Saudi Arabia, 11-12 April 2006.

19. Ivančević, V.; Knežević, M.; Luković, I. Academic Achievement and Choices of Computing and Control Engineering Students in relation to Gender. In Proceedings of the 41st SEFI Conference, Leuven, Belgium, 16-20 September 2013.

20. Peixoto, A.; González, C.S.G.; Strachan, R.; Plaza, R.; Martinez, M.A.; Blazquez, M.; Castro, M. Diversity and inclusion in engineering education: Looking through the gender question. In Proceedings of the IEEE Global Engineering Education Conference (EDUCON), 2071-2075, Santa Cruz de Tenerife, Spain, 17-20 April 2018.

21. OECD. Education at a Glance. In OECD Indicators; OECD Publishing: Paris, France, 2011.

22. De Carvalho Fernandes, M.R.; Madeira, V.R.; da Gama Afonso, H.C.A.; Da Silva Duarte, K.; de Souza, A.L.L.; Peixoto, A. A Study on the Support for Women in Engineering Courses. In Proceedings of the 2019 IEEE Global Engineering Education Conference (EDUCON), Dubai, United Arab Emirates, 8-11 April 2019; pp. 1237-1240. 
23. Botella, C.; Rueda, S.; López-Iñesta, E.; Marzal, P. Gender Diversity in STEM Disciplines: A Multiple Factor Problem. Entropy 2019, 21, 30. [CrossRef]

24. González-Pérez, S.; Mateos de Cabo, R.; Sáinz, M. Girls in STEM: Is It a Female Role-Model Thing? Front. Psychol. $2020,11$. [CrossRef] [PubMed]

25. Atman, C.J.; Sheppard, S.D.; Turns, J.; Adams, R.S.; Fleming, L.N.; Stevens, R.; Streveler, R.A.; Smith, K.A.; Miller, R.L.; Leifer, L.J.; et al. Enabling Engineering Student Success. In The Final Report for the Center for the Advancement of Engineering Education; Morgan \& Claypool: San Rafael, CA, USA, 2010.

26. Gill, J.; Mills, J.; Franzawy, S.; Sharp, R. Oh you must be very clever! High-achieving women, professional power and the ongoing negotiation of workplace identity. Gend. Educ. 2008, 20, 223-236.

27. Powell, A.; Dainty, A.; Barbara, B. Gender stereotypes among women engineering and technology students in the UK: Lessons from career choice narratives. Eur. J. Eng. Educ. 2012, 37, 541-556. [CrossRef]

28. Rosati, P.A.; Becker, L.M. Student perspectives on engineering. Int. J. Eng. Educ. 1996, 12, 250-256.

29. Gill, J.; Sharp, R.; Mills, J.; Franzway, S. I Still Wanna Be an Engineer! Women, Education, and the Engineering Profession. Eur. J. Eng. Educ. 2008, 33, 391-402. [CrossRef]

30. Smith, A.E.; Dengiz, B. Women in Engineering in Turkey-A Large Scale Quantitative and Qualitative Examination, European. J. Eng. Educ. 2010, 35, 45-57.

31. Ministry of Higher Education in Saudi Arabia. Available online: https://www.moe.gov.sa/en/HigherEducation/ governmenthighereducation/Pages/default.aspx (accessed on 29 May 2020).

32. El-Sherbeeny, A.M. Highlighting the Need for Engineering Education for Females in Saudi Arabia. In Proceedings of the ASEE Annual Conference, Indianapolis, IN, USA, 15-18 June 2014.

33. Minitab. Available online: https:/ / www.minitab.com/en-us/ (accessed on 29 May 2020).

34. Adelman, C. The toolbox revisited: Paths to Degree Completion from High School through College; US Department of Education: Washington, DC, USA, 2006.

35. Astin, A.W.; Oseguera, L. Degree Attainment Rates at American Colleges and Universities; Higher Education Research Institute: Los Angeles, CA, USA, 2005.

36. Attewell, P.; Heil, S.; Reisel, L. Competing explanations of undergraduate noncompletion. Am. Educ. Res. J. 2011, 48, 536-559. [CrossRef]

37. Palmer, R.T.; Maramba, D.C.; Dancy, T.E. A qualitative investigation of factors promoting the retention and persistence of students of color in STEM. J. Negro Educ. 2011, 80, 491-504.

38. Astin, A.W.; Oseguera, L. Pre-college and institutional influences on degree attainment. In College Student Retention: Formula for Student Success; Rowman \& Littlefield Publishing Group: Lanham, MD, USA, 2005; pp. 245-276.

39. Horn, L.; Kojaku, L.K.; Carroll, C.D. High School Academic Curriculum and the Persistence Path Through College; National Center for Education Statistics: Washington, DC, USA, 2001.

40. Koch, N.; Kraus, A.; Cachero, C.; Meliá, S. Integration of business processes in web application models. J. Web Eng. 2004, 3, 22-49.

41. Tinto, V.; Riemer, S. Learning communities and the reconstruction of remedial education in higher education. In Proceedings of the Conference on Replacing Remediation in Higher Education at Stanford University, Santa Clara, CA, USA, 26 January 1998. 